\title{
Muhammadiyah Identity and Muslim Public Good: Muslim Practices in Java
}

\author{
ZULY QODIR*, HASSE JUBBA, DYAH MUTIARIN \& MEGA HIDAYATI ${ }^{1}$
}

\begin{abstract}
The study in the current article intends to explore the conception of the presence of the Islamic religious movement known as Muhammadiyah, which still remains to this day in relation to the life of the Muslim community, including its socio-religious, cultural, economic, and political aspects. Accordingly, a proper understanding of Muhammadiyah is not only achieved through a religious approach, but also by examining social-historical conditions, which is by demonstrating the extent that its presence in conducting religious activities correlates with the true concept of Islam (Muslim Public Good). The current study aims to observe the models and strategies utilized by Muhammadiyah's champions in repositioning and reflecting on religious movements, which have been framed at both conceptual and practical level. Subsequently, the framing strategies were used as a social capital to carry out their religious activities. For issues that are practical in nature, the study in this article is a description and elaboration about the aspirations, perceptions, intentions, ideas, goals, and thoughts pertaining to a social system inspired by the spirit of religiosity in Indonesia, in general, and Islam in Java, in particular, within the Muhammadiyah tradition as a Muslim public good (the true Islam).
\end{abstract}

Keywords: Muhammadiyah, Identity, Muslim Practice, Public Good, Village of Java

It is rather challenging to study Islam, including Muhammadiyah, in island of Java. The variance of Javanese religiosity (Geertz 1976), how Javanese communities practiced religion, particularly among farmer and trader communities, widely differed. The category of santri (a devout and correct student of Islam) and non-santri (otherwise known as abangan) continues to be debated (Burhani 2017). Santri has experienced progressive growth in Java in response to abangan (Wajdi 2018). Pranowo also criticizes Geertz on the Islamic practices of Javanese community in the New Order era, 19661990. In his study, villages in Java is often considered as a place of criminal exploits, brutal mischiefs such as fights, robbery, gambling, indecent sexual activities-adultery, and various other crimes that signify village violence (Pranowo 2009).

The Tengger community is also quite familiar with issues of interreligious struggles in Java, wherein Islam confronts another religious tradition, namely Hinduism. The rural areas near Tengger and Bromo consist of villages that are in mutual contestation between Islam and Hindu, in which religious preachers and the state played a role in converting the people of Tengger and Bromo to

\footnotetext{
${ }^{1}$ Zuly Qodir*, Ph. D. (Corresponding author) Senior Lecturer at. Islamic Politics Dept., Universitas Muhammadiyah Yogyakarta, Jl. Brawijaya Tamantirto, Bantul, YOGYAKARTA, Indonesia Email: zuly_qodir@yahoo.com; Hasse Jubba, P.h. D., Lecturer at Islamic Politics Dept., Universitas Muhammadiyah Yogyakarta, YOGYAKARTA, Indonesia. Email: hasse@umy.ac.id; Dyah Mutiarin, Ph. D., Senior Lecturer of Magister of Government Affairs and Administration, Universitas Muhammadiyah Yogyakarta, YOGYAKARTA, Indonesia. Email: mutiarin71@gmail.com; Mega Hidayati, Ph. D., Lecturer of Islamic Politics Dept., Universitas Muhammadiyah Yogyakarta, YOGYAKARTA, Indonesia. Email: mega.hidayati@umy.ac.id
} https://doi.org/10.24035/ijit.19.2021.203 
Islam (Hefner et al. 1999). East Java, during Soeharto's era, subsequently served as a field of battle between Islamism and Hinduism (Hakim 2016; Minardi 2018).

Specifically, for Muslim communities in Java (Yogyakarta), Mark R Woodward explains that there are variations in practicing Islam, one community practices Islam by complying with sharia (normative) while another does not (non-normative). The non-normative group is often identified as Kejawen (Islamic followers) in their Islamic practices, which is different from normative or shariabased Islam (Woodward 1989). (Woodward 2011) elaborates that, within the broader context of Islam's development in Java, there are people practicing Islam by adopting shamanic practices (dukun), exorcism treatments (rukyat), and art performances that are deemed inappropriate with the teachings of Islam, namely jathilan-kuda lumping (dance depicting a group of horsemen). The issue of Javanese Islam has even become something that is most accommodating (Hilmy 2013). While, on the other hand, there is religious authoritarianism (Zamzami, Udin, and Aniq 2018) .

'The issue on the contestation of Islam in Java is described by Mc. Ricklefs as a tough competition among various Islamic traditions that have been in Java since the colonial period until the post-reform era. The advent of new groups in Islam, with their Salafism-Wahhabism and jihadist features, cannot be considered as being entirely free from competition to mutually gain greater influence among the masses (Ricklefs 2012). This indicates that there are developments and growth in understanding and practicing Islam in Indonesia. Salafism flourishes in Indonesia (Hasan 2009). This is also an indication that there is a contestation between moderatism and Salafism in Indonesia (Arifianto 2018). Indonesia, a region that is abundant with religious schools and sects, accordingly serves as a nursery for Islam, which is inseparable from Islam in Southeast Asia, in terms of its political, social, and cultural challenges (Nathan and Kamali 2005).

All of the activities found in the Islamic tradition in Java can be considered as a part of sharing the extremely varying religious experiences in the island of Java. Religious sharing was carried out by (Gort et al. 1992) when he explained the possibility of interfaith and interreligious activities in practicing religion that mutually upholds and appreciates differences in various religious traditions. The current article describes the Islamic identity that Muhammadiyah adheres to as a moderate Islam group in Java and the numerous challenges that it has confronted.

\section{Methodology}

The current article employed a sociological approach by prioritizing descriptions of phenomenon developing in the society, and utilizing theoretical perspectives of social movements. Data in the article were obtained through field observations, and literature study in order to describe the latest phenomenon of Muhammadiyah in Java, Indonesia in relation to public good.

\section{Muhammadiyah as a Socio-Religious Movement}

Clifford Geertz in Mojokuto circa 1950s and his comparative research in Tabanan, Bali concerning Javanese society (Geertz 1963) have inspired numerous scholars to conduct similar research, although by using slightly different perspectives. In his book, Geertz analyzed the relationship between Islamic renewal and the increase of Javanese society's economic growth. Geertz revealed a close relationship between the two. This conviction was proven by Geertz based on his research findings showing that out of seven modern shops that remained standing in Mojokuto, six of them were operated by reformist-puritan Muslims. Most of them were tobacco and textile business leaders who, economically speaking, were more well established and prosperous. Such positive correlations subsequently convinced Geertz that Islamic reform in the form of puritan Muslim is the doctrine followed by the majority of traders.

https://doi.org/10.24035/ijit.19.2021.203 
Irwan Abdullah, (Abdullah 1994) concluded that religious devotion may play a significant role in the process of thought renewal, which consequently leads to economic behavior and influences the way that the population accept trading activities in their life. According to Abdullah, the small traders and businessmen identified in the study are followers of Islam with a modern understanding, like Muhammadiyah, which has a Calvinist character. They are people who have succeeded in translating their religious understanding into a reformist understanding that encourages the creation of a spirit of progress and successful business endeavors. The spiritual aspect of Islamic understanding reform obeyed by Muhammadiyah followers in Jatinom, Klaten provides a sufficiently solid basis for the trading behavior of Muhammadiyah members.

Despite still being under the influence and shadow of Max Weber's thesis on the Protestant Ethics (Weber 2013). Geertz 1950s research inspired Sukidi Mulyadi, through similar means, to conduct research on the relationship between Muhammadiyah's Islamic reform movement and Calvinist's Protestant reform. He states that both Calvinists and puritan Muslims of Muhammadiyah have some similarities of which among them are: first, both teach scriptualism of holy text (sola scriptura). Second, they maintain a similar slogan of "returning to the holy book". This is known as the sola fide doctrine, which teaches that the absence of an intermediary system between God and His people is reflected in the attitude to minimize elements of the sacrament, radical delegitimation of the priesthood system, and objection to the hierarchical church. Third, both Calvinists and puritan Muslims of Muhammadiyah reject irrational and magical elements in seeking salvation. This principle was theorized by Weber in his thesis as "disenchantment of the world". Mulyadi concludes that the puritan Muslim group struggles in two things: exclusion of magical elements from Islam and demystification of worldly conception, more rational and ascetic way of life in the modern world.

The Calvinist ethics, which put emphasis on values of virtue, honesty, and hard work in business activities, are then modeled in the daily life behaviors of Kiai Haji Ahmad Dahlan, the founder of Muhammadiyah. Dahlan is the prototype Muslim Calvinist - as an inner-worldly ascetic. He was able to change the Javanese world that tended to be magical, traditional, and non-rational into a life attitude that is rational and imbued with the spirit of modernity and progress. Islam in the hands of Dahlan seems to become more progressive, rational, and even liberal.

Reformist-puritan Islam in Javanese society does, undoubtedly, indicate a positive tendency when observed form an economic perspective. (Latief 2013; Nakamura 2012), state that 'orthodox Islam' or 'Islam orthodoxy' can survive and even progressively flourish in communities that have strong heterodox tradition and Javanese culture. Muhammadiyah in Kota Gede, Yogyakarta when observed externally gives the impression of being very rigid, closed, fanatical, and anti Javanese culture. However, when "going inside', Muhammadiyah in fact demonstrates a paradox to its apparent features, such as: being flexible, tolerant, open, and njawani (having a sense of Javaneseness) and critical to government (Tohari, 2020). Muhammadiyah gains support from Javanese communities with strong heterodox basis. Islamic heterodoxy serves as a substantial part of the modernist Islam movement in Indonesia for the sake of maintaining purifications that have long been followed from teachings deemed as syncretic (Saleh 2001).

Muhammadiyah is unlike Nahdlatul Ulama that develops closer religiosity with Sufis. Muhammadiyah does not develop much institutional Sufism traditions. If there are Muhammadiyah figures who practice Sufism throughout their life, it is merely a personal behavior instead of organizational. Muhammadiyah tends to develop shariah and theological purification, which results in its seemingly rigid religious practice. In developing their theology, the modernist group reconstructed the Ash'ari (Sunni) theological understanding into Rationalist-Mu'tazila by still maintaining Islamic orthodoxy (aqidah) (Saleh 2001:155-69) .

(Burhani 2010) considers that several Javanese elements have become an integral part of its identity. Although Muhammadiyah had maintained its puritan ideological characteristic since the

$$
\text { https://doi.org/10.24035/ijit.19.2021.203 }
$$


two decades of its initiation, it constantly demonstrates a high appreciation toward Javanese culture. Muhammadiyah experienced a shift toward a strong puritan orientation. This is observed from the affiliation of several Sumatran Muslim figures who possessed puritan beliefs and character, the establishment of Majelis Tarjih that influenced the formation of the sharia paradigm. Hilman Latief refutes Burhani's argument that Muhammadiyah underwent puritanism revival. Latief argues that Muhammadiyah since 1990s to 2015 had undergone a post-puritanism movement, which indicates moderation in Muhammadiyah. (Latief 2017).

Muhammadiyah's contestation, accommodation, and negotiation are the interesting features of puritan-modernist Islam. The unique characteristics of Muhammadiyah's purification movement were classified by Abdul Munir Mulkhan (Mulkhan 2000a). Mulkhan distinguishes four categories of Muhammadiyah members: first, Muhammadiyah "ikhlas", which refers to Muhammadiyah members who have sincere puritan orientation. Second, Muhammadiyah "Ahmad Dahlan", which refers to those bearing a moderate character in interacting with the others. Third, "Muhammadiyah-Nahdlatul Ulama" (MUNU), which refers to Muhammadiyah members who practice the traditionalist worshiping model. Fourth, "Marhaenis-Muhammadiyah" (MARMUD), which refers to Muhammadiyah followers who have a strong secular nationalist-political orientation, are slightly "leftist", admire Soekarno, and a sympathizer of nationalist party.

Alwi Shihab, (Shihab 2016), highlights the birth of the Muhammadiyah movement and its operation. Shihab revealed various factors that underlied the establishment of the Muhammadiyah movement. He stated that its initiation process was caused by presence of missionaries penetrating the land. According to Shihab's study, it is stated that a religious movement emerges when there is evident pressure threatening the continuity of religious life. Christian missiology was accordingly balanced by similar movements inspired by modern movement of Christian-Calvin in Java during the Dutch colonial era.

Hyun Jun Kim, explains how a village in Java (Yogyakarta) underwent changes in religious behavior due to the advent of a "reformist", although he did not consider himself as a reformer (Kim 1996). In villages, it is often the case that religious behaviors do not necessarily alter traditional practices that have been conducted for ages. There are accommodations and dialectics in place. In Java, there are numerous followers that do not have a Muhammadiyah member card, yet in terms of religious practices they adhere to the traditions of Muhammadiyah, which is deemed as the reformist puritan-modernist group. The Javanese are exceedingly pliant and accommodative with Javanese traditions, but they still uphold Islamic traditions as well.

Mark Woodward states that there are numerous religious practices that are continued to be conducted throughout Java and Indonesia, like practices of shamanism (dukun), slametan (communal feast), and mitoni (ritual performed when woman is at her $7^{\text {th }}$ month of pregnancy) which are often classified as bid'ah (creating new practice without precedence) and even heretic (Woodward 2011). These are even observed in villages that are considered to follow Muhammadiyah's religiosity. This is because the spread of Islam did not simply prohibit or penalize religious practices that have become a part of the "Javanese spirit". Being Javanese is to become a true human being. Islam as a religion refers to one's closeness with the "jagad gede" (the grand universe). Whereas becoming Javanese refers to "jagad alit" (the infinitesimal universe), in which the two would not collide but fill each other, complement one another instead.

Without labelling Muhammadiyah as a Salafist-jihadist or even Wahhabi organization, in fact, some of Muhammadiyah's Islamic practices are similar with those that follow or are categorized as Salafism and Wahhabism. The difference is that Muhammadiyah, when deemed as Salafism, is rational Salafism. This is because Muhammadiyah still follows the Islamic understanding outlined by Muhammad Abduh and Muhammad Rasyid Ridho from Tafsir Al-Manar (Quranic exegesis). Therefore, although Muhammadiyah is considered as Salafism, it is moderate Salafism (Nashir 2010). In its recent development, Salafism-Wahhabism has shown expansive influences up to the local level.

https://doi.org/10.24035/ijit.19.2021.203 
There are studies that comprehensively discuss the various aspects of Salafism and its dissemination throughout numerous countries (Meijer 2009).

\section{Muslim Public Good}

Concerning Muslim Public Good, Armando Salvatore and Dale F. Eickleman explain that the Muslim community is currently putting their attention to how they can present Islamic virtues (Muslim public good), following the wave of suicide bombings in Indonesia, Africa, Europe, and America. The Muslim community intends to present a face of Islam that is different from the one presented by a small group of Muslims who perform acts of violence to others. The idea of Muslim public good was inspired by the history of Muhammad's prophethood in which he was present as a religious leader, a state leader, and a Muslim community leader amidst the diverse population. Muhammad did not force his will upon others, respected differences, honored the basic rights that followers of different religions have, served anyone in need, was sympathetic, polite, and a fair enforcer of the law. All of these are Islamic features that are historically irrefutable, yet along the way they have been challenged by a minority group that has distorted Islam, a religion that is truly rahmatan lil alamin (a mercy to all creation). In Indonesia, Muslim public good is presented by Islamic organizations like Muhammadiyah as a modern Islamic organization with a Calvinist model, as stated by Clifford Geertz, Irwan Abdullah, and Sukidi Mulyadi (Salvatore and Eickelman 2004).

The link between religiosity and piety is argued by (Mahmood 2005) that, critically speaking, there is nearly not one activity that can truly be said as originally (purely) in the form of individual piety or social piety. Accordingly, every form of piety or public good will be associated with the public dimension that is known as politics. Piety is also associated with issues of public politics as a part of religious contestation. Mahmood, subsequently, correlates the contestation between traditionalist Islam and revivalist Islam using the perspective of critical feminism. Even Linda Herera and Asef Bayat did not refute the argument Mahmood presented. In the case of young Muslims, Islam is constantly connected with political issues as a formation of the image as a Muslim (Bayat and Herrera 2010).

Specifically, Sudibyo Markus explains that Muslim Public Good (true Islam) has five unique characteristics, namely: first, a structure of a community that has faith, piousness, and practices Islamic teachings continuously (kaffah) as a process, and is united to uphold Islamic brotherhood. This is the meaning of the Muslim community that is saved by Allah from digressions, so that it should save other members of the community by performing virtues, prohibiting vices; second, a community that has excellent characteristics in performing virtues by doing good and prohibiting misbehaviors; third, life has a purpose and it is organized, people are to strengthen one another, empower one another, have social solidarity, and care for one another: fourth, it should be compassionate (caring, not stubborn or selfish, forgiving, prioritizing dialog rather than violence and obtrusion of opinions, merely wishes for God's blessing in doing good deeds; and fifth, develops open and tolerant attitude toward others by upholding the teachings of Islam. Not be capricious, maintains a solid stance yet able to accept the different views, thoughts, and arguments presented by others (Markus 2009).

The religious movement approach is an unavoidable issue. Keeping in mind that Muhammadiyah is known as a socio-religious Islamic organization that engages the community in various religious, cultural, economic, and political activities that forms the characteristics of this organization. The five characteristics above are the key formula of Muslim Public Good in Muhammadiyah that will be used as a reference in analyzing Muhammadiyah as a religious movement. 


\section{Religious Movement}

Studies on religious movement have also been copiously done. For instance, (Kartodirjo 1984:9-10) did a research on religious movements in Java that were developing at the end of the 19th century and the beginning of the $20^{\text {th }}$. The study emphasized on the trail of Ratu Adil (the just king) in Java. In the research, numerous religious movements in Indonesia were found to be of millenarian character. These movements were given various names, such as messianism, millenarianism, nativism, prophetism, and revitalism or revivalism.

This can be observed from the fact that these religious movements tended to model the structures of Ratu Adil teachings or in waiting of the advent of the messiah (Kartodirjo 1984:9). This can also be observed in the Nyi Aciah incident, 1870-1871; the Amat Ngaisa movement or the Kobra movement, 1871; the Jasmani incident, 1888; and the Tangerang incident, 1924, which are all trails of religious movements throughout Indonesia in the pre and post-colonial periods (Kartodirjo 1984:11). The study reminded scholars interested in history not to overlook minor events of social movements that can serve as objects of study. It is, thus, important to historically track the religious movements that took place in various regions throughout Java.

During the reform era (Rahardjo 1993) wrote about the role of religious movement in strengthening civil society by focusing his analysis on the vision that every religion-based mass organizations and NGOs have concerning the process of reinforcing civil society. In this context, Rahardjo presents a comparison of the visions, strategies, concepts, and programs of mass organizations and NGOs that were engaged in community empowerment. In turn, the NGOs were able to cultivate a system of religious values that can function as synergy and vision for the process of strengthening civil society. The research produced a new format of religious movement that is considered as being more compatible with the democratic vision and ethos of civil society.

Situmorang, in relation to social movements that offer a New Social Movement model, conducted a case study on several examples of public resistance in Indonesia (Situmorang 2013). Situmorang applied a number of social movement theoretical approaches and provides elaborations on those theories, which have experienced developments in the 1960s and even more progressively so during the period leading up into the $21^{\text {st }}$ century. The emergence of new social movements is indicated with the increasingly diverse actors engaged in social movements such as students, professionals, and women, who no longer serve as a part of the farmer and labor portfolio. As for the issues that these actors aim for include basic human rights, democratization, women/gender, environment, and inequality, and consequently, the study of social movement had shifted from being centralized into becoming more scattered among various centers of scientific discipline.

Qodir states that small-scale Islamic religious movements are able to influence larger religious movements in order to achieve their political goal. The author took a number of cases in demonstrations that were conducted on behalf of religion as a basis in their political struggle. Nonetheless, religion should be aware that, aside from having an impact in altering religious understanding, economic change can also become a part of social movement that are based on the intrinsic values of religion (Qodir 2009).

Although socio-religious movement approach is not clearly mentioned in Muhammadiyah, studies that position social movements with religious nuances into the social movement frame of analysis have been initiated and can be cited from a number of past research. In Qodir's study on Islamic social movement, it is briefly mentioned how Muhammadiyah should proceed in alleviating poverty among the Indonesian population. Muhammadiyah is expected to not only be active in aspects pertaining to revival of Muslim faith and sharia.

Studies by (Wiktorowicz 2004) and (Wickham 2002) that observed the Salafi movement and Ikhwanul Muslimin in Egypt and Jordan, and by (Hasan 2006) and (Prasetyo 2002) that examined Laskar Jihad, are examples that put religious movement in social movement's frame of analysis.

$$
\text { https://doi.org/10.24035/ijit.19.2021.203 }
$$


There is also a study conducted by (Arifin 2005) that referred to social movement practices and ideology of fundamentalist groups by taking the case of the Hizbut Tahrir movement in Indonesia as a subject of study. Various studies that have been done mostly observed Islamic movements that have political ends. Salafism-Wahhabism-jihadist serves as a highly intensive topic of study among researchers in the last twenty years following the 2001 Bali bombing incident.

The current study attempts to use the previously mentioned social movement observations as a reference by making the case of Muhammadiyah's Islamic movement in relation to Islam Public Good as a basis of analysis, to be more specific, it is analyzed as a mainstream Islamic movement in Java other than Nahdlatul Ulama (NU). In the classical theory, social movement is always seen as a form of defiance against the mainstream. However, in the subsequent period, social movement has its own place in social theory. In recent modern discourse, social movement is always pitted against new social movement theory. The advent of this latest theory is considered to have revised the initial theory as it brings along with it a new spirit, which is post-materialism, but it still advocates libertarianism, although this assumption is rejected by supporters of the social movement theory. In line with the above, (Williams 1994:786) defines social movement as follows:

"Social Movements are socially shared activities and beliefs directed toward the demand for change in some aspect of the social order. To the narrow: a social movement is a formally organized group that acts consciously and with some continuity to promote or resist change through collective action".

According to the above definition, social movement is an organized movement with the aspiration and goal of "promoting" or "resisting" change in some aspects of the existing social order in a conscious, continuous, and collective manner. Meyer and Staggenborg, specifically, define social movement as a movement that counters or opposes institution of state, where it is involved in the interaction process among various social movements and social change itself (Meyer and Staggenborg 1996).

In a lot of cases, religious movements come into contact with numerous social issues and agendas that relate to public rights and interests. Within this framework, religious movements have the power to articulate political awareness in public space without having to go through the mechanism of practical politics (Beck, Giddens, and Lash 1996:22) categorize this model as the subpolitics movement, or it is also understood as non-parliamentary political movement.

\section{The Real Muslim of Public Good Society}

As presented in the framework that is used as a basis in explaining Muslim Public Good in the above passages, there are five unique features. All five function as Muhammadiyah's Islamic guide when conducting their activities in Java and Indonesia. It should be noted that discussing about Java is no simple task, Java is a complex subject matter with various crucial and interrelated issues; be it economy, politics, culture-traditions, and religiosity. Even in terms of village economy, there are grave issues concerning land acquisition and cultivation. There is also the issue of extremely diverse religious understandings, which is not only Islam but kejawen (traditional Javanese belief) as well (Hefner et al. 1999:3-10). Accordingly, discussing Java requires caution to avoid any misunderstanding.

In the context of religious practice and understanding in Java, Muhammadiyah's endeavors in da'wah (spreading and conveying the message of Islam) by using oral speeches and actions (activities) so that both are combined between matters of human speech and action. This relates to what is considered as Islam that is kaffah (complete, perfect), which is a process of becoming Islam Islam in terms of speech or activity as a form of true Islam. In Java, as commonly known, there are

$$
\text { https://doi.org/10.24035/ijit.19.2021.203 }
$$


numerous religious groups found in Islam or schools of mysticism (kebatinan), and Muhammadiyah tries to exist amidst the abundance of schools in Islam and Javanese mysticism, which consequently leads to Muhammadiyah preferring a more open stance toward differences and tolerance toward various religious traditions, instead of a stubborn and hard-headed attitude (Markus 2009).

As a socio-religious movement, Muhammadiyah continues to engage in $d a^{\prime} w a h$ activities that is better known as da'wah amar ma'ruf nahi munkar (the call/invitation to commanding the good and forbidding the evil) within the frame of Islam Rahmatan lil alamin (Islam as a mercy to all creation), Islam that is moderate (tawasuth) and progressive (tajdid) (Nashir 2014). Muhammadiyah does not leave behind religious understandings that advance the Muslim community in all aspects. Muhammadiyah endeavors to enrich the life of the nation through educational activities. Muhamadiyah carries out da'wah by empowering poor communities in rural areas throughout Java. Muhammadiyah develops a puritan Islamic tradition, which means purifying matters that are considered as superstition and heresy (tahayul, bidah, and khurafat), and consequently a delegate making supplication to God is not introduced in Muhammadiyah's theology. Muhammadiyah does not recognize the term tawasul in worship. (Peacock 1978) There has been a push and pull between progressive and conservative theologies in Muhammadiyah (Asyari 2007) There is Islamic revival (Arifianto 2019).

Meanwhile, in terms of public service activities in the spirit of practicing al-Maun, Muhammadiyah does not differentiate people who are Muslims or aren't, people who are Muhammadiyah or NU members, everyone receives similar social services regardless. This is a part of Muhammadiyah's public good, which is a tradition of the modernist group. By providing the people with social services, Muhammadiyah has proven that it is an organization that empowers the community as a part of its philanthropic undertakings (Latief 2010). The philanthropic tradition (charity) has long been developed in Christianity and Catholicism in order to serve congregations in need. Charitable activities are done in order to provide scholarships, foodstuff for daily needs, and incidental medications (Bartkowski and Regis 2003).

The concept of $d a^{\prime} w a h$ bil lisan and bil amal (preaching through speech and practice) serves as a guide for Muhammadiyah to engage in social activities in Java. Muhammadiyah is well aware that da'wah (the spread of Islam) will not be a part of the society's life and blood if impoverished communities are only given religious lectures. In Muhammadiyah's conception, lectures without action is considered to go against the spirit of al-Maun, which is the spirit to empower the impoverished, the homeless, and orphans. This contradicts the initial spirit of Muhammadiyah founded by KH. Ahmad Dahlan (Arifin 1990; Mulkhan 1994).

Another intriguing aspect of Muhammadiyah in Java is its political identity and choice since the 1955 election up to the 2019 Reform era. Muhammadiyah does not establish a political party, although there is the National Mandate Party (Partai Amanat Nasional - PAN), which is closely associated with Muhammadiyah, but not all members of Muhammadiyah in Java support PAN in the post reform general election (Asyari 2009) explains that although Muhammadiyah has close political contact with PAN outside of Java, it still remains independent. While Muhammadiyah claimed to have approximately 35-40 million members, PAN as a party that has a close relationship with Muhammadiyah actually only secured 7.8 million votes (Bush 2014; Mujani 2007; Nashir et al. 2019).

It seems that Muhammadiyah's identity in Java in terms of religiosity, tradition, and social services is a manifestation of the practice of public good, which is performing teachings of faith in God. Wherein faith must have an impact on social issues such as helping the poor, easing the burden of the needy, educating the obtuse and uneducated, and maintaining the purity of faith from inauthentic teachings of the Quran and Hadith. In this case, Muhammadiyah places identity as an inseparable part of faith in God. The various forms of piety (public good) carried out by Muhammadiyah are a form of multicultural piety practices. These practices of piety (public good) exist within a jungle of social identity diversity in practicing religion and making political choices.

$$
\text { https://doi.org/10.24035/ijit.19.2021.203 }
$$


Such particular kind of piety or public good is considered as authentic piety from those who have faith in God (Mulkhan 2005).

The theological dimension, as the initial mission of Muhammadiyah's activities in Java that continues to develop all over Indonesia, with its puritan-modernist theological perspective, has led to the creation of a Muslim community with a progressive understanding of Islam (Burhani 2017). Muhammadiyah's presence in Java is inseparable from the continuity of a Javanese Islamic understanding that tends to have a more abangan (syncretic or cultural Muslim) dimension as an inherent culture of Javanese Islam (Burhani 2017). Religious understanding in Java is extremely varied. The 2019 political year also witnessed a very significant change which raised the concern of a destruction of democracy (Mujani 2019).

With regard to social service as a manifestation of Muhammadiyah's muamalat (commercial and civil acts or dealings under Islamic law) and political practice, it provides an outlook of Muhammadiyah's characteristic in Java. Muhammadiyah's identity in Java is strong because the bond of Islamic dimensions advised by the leaders to the members are highly intensive (Qodir 2009) .

In terms of virtue, Muhammadiyah is significantly strong. All are unique features of Muhammadiyah in Java with a robust Javanese culture. Muhammadiyah negotiates, challenges, and accommodates Javanese traditions that have widely spread beforehand. Nevertheless, Muhammadiyah's bond with its members is so solid that an excellent understanding of Islam, as the true Islam, becomes a defining feature of Javanese Muslim community (Qodir 2009). This is in accordance with Muhammadiyah as a true identity in terms of religiosity, social hospitality, cultural identity, and political identity, which is occurring in the Javanese Muhammadiyah Muslim community in Yogyakarta as a case study in creating identity to become Muhammadiyah. Without giving any impression of violence to those who hold different theological, cultural, religious understandings, and political preference. Muhammadiyah exists in the midst of Javanese society that has accepted Hinduism and Buddhism and other Javanese religious beliefs (Qodir 2018).

\section{Muslim Practices in Java: Cultural Identity of Muhammadiyah}

The Islamic practices in Java that Muhammadiyah brought have led to a specific Muslim community feature in terms of tradition and culture. Accordingly, the tradition that Muhammadiyah follows is one that do not contradict the teachings of Islam while not blatantly objecting to various cultural events. Muhammadiyah's cultural practice that accommodates Javanese culture becomes the unique character of Muhammadiyah with its diverse thoughts and expressions in becoming Muhammadiyah (Burhani 2019; Mulkhan 2000b).

In the context of social relations and maintaining good relations with communities (social cohesion and harmony), Muhammadiyah continues to apply the principle of maintaining social harmony in its social interactions. The principle of Belief in the One and Only God $\left(1^{\text {st }}\right.$ principle of Pancasila, Indonesia's 5 philosophical foundations) as Muhammadiyah's theology of tawhid (the indivisible oneness of God; monotheism principle in Islam) does not collide with social diversity as a manifestation of conducting the first principle of Pancasila (Mu'thi and Burhani 2019). This, concurrently, strengthens Muhammadiyah's understanding of the Pancasila Nation as darul ahdi wa syahadah (the basic principle that Indonesia mutually belongs to all its people and that it should be jointly developed, protected, and maintained from destruction), which functions as Muhammadiyah's official consensus (Muhammadiyah 2015). Acknowledging the different others is an irrefutable reality within a society that consists of various ethnicities and religions (Nygren, Martinsson, and Mulinari 2018).

https://doi.org/10.24035/ijit.19.2021.203 


\section{Muhammadiyah's Identity and Its Differences with Others}

Muhammadiyah in Java and Indonesia, generally, applies a moderate (tawasuth) level of religious understanding, instead of an extreme right or an extreme left one. Muhammadiyah's tolerant and moderate stance has been its trademark since its foundation until today in the $21^{\text {st }}$ century (Burhani 2019). Nonetheless, Muhammadiyah's moderate understanding is challenged by conservative and Salafism groups that have been developing throughout Indonesia from non-religious campuses (Arifianto 2018) Muhammadiyah exists within a competition between progressivism and conservatism (Asyari 2007).

Cultural identity, religious understanding, and the differences between Muhammadiyah and other socio-religious organizations in Java is based on the interpretations of texts in the Quran and Hadith, which is conducted by following modern tradition and in a rational manner. As mentioned by Nasr Abu Zayd, the Quran and Hadith should be interpreted in a modern way so that the Muslim community can undergo a revival in Islamic thoughts (Zayd 2006:30-34).

Muhammadiyah's moderate religious understanding has been its trademark from the start. Is just that, recently, such moderate understanding has been challenged by various religious schools that emerged following Indonesia's 1998 political reform. This trend can be considered as a swing of the Islamic conservatism pendulum in Indonesia (Bruinessen 2013). Muhammadiyah's moderatism has been challenged by conservative groups within Muhammadiyah itself since 2005 during the 2005 Muhammadiyah Conference in Malang (Burhani 2019). Islamic conservatism swinging in from campuses and Islamic social organizations have rendered Muhammadiyah in need of truly modifying its da'wah model so that its congregation does not leave Muhammadiyah for other organizations such as Majelis Mujahiddin and Majlis Tafsir al-Qur'an (Singh and Qodir 2015).

The diversity of (Islamic) religious understanding in Java and Indonesia in general distinctly distinguishes Islam that is observed here in Indonesia and in the Middle East. Indonesia's Islamic diversity provides an abundance of democratic traditions and political changes that have appeared since 1998. There is a rise of sharia in Indonesia, yet it does not challenge democracy as a political practice (Dijk and Kaptein 2013). Indonesia and Java's Islamic diversity should be continuously managed so that it does not become counterproductive to matters that relate to religious freedom (Bagir 2014). If diversity is managed improperly, anxieties will emerge, contradictions will appear, a climate of political democracy develops, but it is not followed by a sense of freedom in adhering to one's preferred religion and expressing one's preferred faith (Menchick 2016).

Thus, Muhammadiyah, as an influential Islamic organization in Indonesia and Java, in particular, needs to advocate religious freedom, especially, for minorities. Religious minority groups in Java and Indonesia are still experiencing discriminatory treatments, hatred, and acts of violence from small Muslim groups. The need to advocate religious freedom is a specific challenge that Muhammadiyah in Indonesia and Java is facing (Bagir 2014). The Towani Tolotang case in South Sulawesi (Jubba 2019a) is an example of a minority group that requires the attention of Muhammadiyah, which has quite significant political clout (Jubba 2019b).

Muhammadiyah in Java is an Islamic organization with high level of excellence in terms of true Islamic experiences when compared to other Islamic organizations. Muhammadiyah in Java sets itself apart from other Islamic organizations through the various social activities it engages in, such as serving communities in need, the uneducated, and orphans as a form of Muhammadiyah's social charity, which is complementary to Muhammadiyah's more puritan (purification of belief/faith) and sharia-oriented theological understanding.

From the explanation given above, Muhammadiyah in Java has a strong characteristic in maintaining Muhammadiyah's identity. As Muslims they continue to attach themselves to Muhammadiyah despite of their rural residence. Nonetheless, they harbor no ill will toward others in their social activities. The spirit of mutual help and cooperation in social affairs, keeping the

$$
\text { https://doi.org/10.24035/ijit.19.2021.203 }
$$


brotherhood of social solidarity, these are the unique features of Muhammadiyah in Java. In terms of Islamic practices, Muhammadiyah seems to be more scriptural when compared to other organizations like NU, which is another side of Islam in Java. Muhammadiyah's puritan practices originate from an understanding of Islamic teachings taken through official decisions made and sternly followed by Muhammadiyah.

Muhammadiyah in Java has a uniqueness in maintaining its cultural identity. Muhammadiyah does not oppose the various traditions present in Java so long as they do not go against Islamic teachings that are absolute in nature. Muhammadiyah is also uninvolved in numerous traditional practices that are considered as having indefinable references such as performing Weekly Slametan (Javanese communal feast), Wetonan (Javanese calendar based events/rituals), One Hundred Days commemoration of the dead. Muhammadiyah does not commemorate a person's death, which is known as Khaul (Commemoration of Death), but it also does not disband or oppose the ritual. As long as it is not deemed as sharia related, Muhammadiyah lets it be as a tradition of the Muslim community that must be understood in an Islamic sharia manner that is straight and correct (true Islam), which is typical Islamic purification.

Muhammadiyah in Java holds a particular pride on account of the activities and differences that this modernist organization maintains. The numerous activities that Muhammadiyah engages in makes it confident and firm amidst the social turmoil of Java. The fact that there are some Muhammadiyah members who opted to "shift orientation" toward other socio-religious organizations is regarded as natural, since Muhammadiyah is an open and moderate organization. Muhammadiyah's moderateness, on the one hand, renders it flexible and accommodating with current developments, while on the other hand, it may easily be influenced by other views and movements going into Muhammadiyah.

Observing what Muhammadiyah has done in Java, between Islamic affairs, identity, and tradition, these are three things that not only negotiate, and accommodate one another but they are also engaged in mutual contestations in terms of public good. Muhammadiyah does not consider Java and its diverse traditions and ethnicities as an adversary, but more like a partner in carrying out social activities, despite of the differences in puritan theological understanding. Muhammadiyah's purification is based on the Quran and Hadith, which are authentic references for practicing Islam in a way that brings mercy to all creation (rahmatan lil alamin).

\section{References}

Abdullah, Irwan. 1994. The Muslim Businessmen of Jatinom: Religious Reform and Economic Modernization in a Central Javanese Town. Ph.D Thesis. Amsterdam: Universiteit van Amsterdam.

Abu Zayd, Nasr. 2006. Reformation of Islamic Thought: A Critical Historical Analysis. Amsterdam: Amsterdam University Press.

Arifianto, Alexander R. 2018. Islamic Campus Preaching Organizations in Indonesia: Promoters of Moderation or Radicalism? Asian Security. 15(3) 1-20.

Arifianto, Alexander R. 2019. Rising Islamism and the Struggle for Islamic Authority in PostReformasi Indonesia. TRaNS: Trans -Regional and -National Studies of Southeast Asia. 8(1) 114.

Arifin, M. T. 1990. Muhammadiyah Potret yang Berubah. Surakatra: Institut Gelanggang Pemikiran Filsafat, Sosial Budaya dan Kependidikan.

Arifin, Syamsul. 2005. Ideologi dan Praksis Gerakan Sosial Kaum Fundamentalis: Pengalaman Hizbut Tahrir Indonesia. Malang: UMM Press.

https://doi.org/10.24035/ijit.19.2021.203 
Asyari, Suaidi. 2007. A Real Threat from within: Muhammadiyah's Identity Metamorphosis and the Dilemma of Democracy. Journal of Indonesian Islam. 1(1):18-41.

Asyari, Suaidi. 2009. Nalar Politik NU-Muhammadiyah; Overcrossing Java Sentris. Yogyakarta: LKIS.

Bagir, Zainal Abidin. 2014. Mengelola Keragaman dan Kebebasan Beragama di Indonesia: Refleksi Atas Beberapa Pendekatan Advokasi. Yogyakarta: Center for Religious and Cross-cultural Studies.

Bartkowski, John P. and Helen A. Regis. 2003. Charitable Choices: Religion, Race, and Poverty in the Post-Welfare Era. New York: New York University Press.

Bayat, Asef and Linda Herrera. 2010. Being Young and Muslim: New Cultural Politics in the Global South and North. Oxford: Oxford University Press on Demand.

Beck, Ulrich, Anthony Giddens, and Scott Lash. 1996. Reflexive Modernization: Politics, Tradition \& Aesthetics in the Modern Social Order/Review. Canadian Journal of Sociology. 21(3):427.

Bruinessen, Martin Van. 2013. Conservative Turn: Islamic Fundamentalism Threat. Singapore: ISEAS Publishing Institute of Southeast Asian Studies.

Burhani, Ahmad Najib. 2010. The Muhammadiyah's Attitude to Javanese Culture in 1912-1930. Jakarta: Al-Wasath Publishing House.

Burhani, Ahmad Najib. 2017. Geertz's Trichotomy of Abangan, Santri, and Priyayi: Controversy and Continuity. Journal of Indonesian Islam. 11(2):329-50.

Burhani, Ahmad Najib. 2019. Trends in Southeast Asia: Between Social Services and Tolerance: Explaining Religious Dynamics in Muhammadiyah. Singapore: ISEAS-Yusof Ishak Institute.

Bush, Robin. 2014. A Snapshot of Muhammadiyah Social Change and Shifting Makers of Identity and Values. Singapore: Asia Research Institute National University of Singapore.

Dijk, C. van and Nico Kaptein. 2013. Regime Change, Democracy \& Islam: The Case of Indonesia. Leiden: Leiden University.

Geertz, Clifford. 1963. Peddlers and Princes: Social Development and Economic Change in Two Indonesian Town. Chicago: University of Chicago Press.

Geertz, Clifford. 1976. The Religion of Java. Chicago: University of Chicago Press.

Gort, Jerald D., Hendrik M Vroom, Rein Fernhout, and Anton Wessels. 1992. On Sharing Religious Experience: Possibilities of Interfaith Mutuality. Michigan: Grand Rapid.

Hakim, Masykur. 2016. Soeharto and the Politicization of Indonesian Islam (1968-1998). Journal of Indonesian Islam. 10(2):159-80.

Hasan, Noorhaidi. 2006. Laskar Jihad: Islam, Militansi, dan Pencarian Identitas di Indonesia Pasca Orde Baru. Jakarta: LP3ES.

Hasan, Noorhaidi. 2009. The Making of Public Islam: Piety, Agency, and Commodification on the Landscape of the Indonesian Public Sphere. Contemporary Islam. 3 (3), 229-50.

Hefner, Robert W., A. Wisnuhardana, Imam Ahmad, and Imam Baehaqi. 1999. Geger Tengger: Perubahan Sosial dan Perkelahian Politik. Yogyakarta: LKIS.

Hilmy, Masdar. 2013. Whither Indonesia's Islamic Moderatism? A Reexamination on the Moderate Vision of Muhammadiyah and NU. Journal of Indonesian Islam. 7(1):24-48.

Jubba, Hasse, Mustaqim Pabbajah, Zainuddin H Prasodjo \& Zuli Qodir. The Future Relations between the Majority and Minority Religious Groups, Viewed from Indonesian Contemporary Perspective: A Case Study of the Coexistence of Muslims and the Towani Tolotang in Amparita, South Sulawesi. International Journal of Islamic Thought. 16 (2): 13-23.

Jubba, Hasse. 2019b. Kontestasi Identitas Agama: Lokalitas Spiritual di Indonesia. Yogyakarta: The Phinisi Press-CissRec dan Politik Islam Universitas Muhammadiyah Yogyakarta.

Kartodirjo, Sartono. 1984. Pemberontakan Petani Banten 1888: Kondisi, Jalan Peristiwa dan Kelanjutannya. Jakarta: Pustaka Jaya.

Kim, Hyung Jun. 1996. Reformist Muslims in A Yogyakarta Village: The Islamic Transformation of Contemporarry Socio Religious Life. Australia: Australia National University.

https://doi.org/10.24035/ijit.19.2021.203 
Latief, Hilman. 2010. Melayani Umat: Filantropi Islam Dan Ideologi Kesejahteraan Kaum Modernis. Jakarta: Gramedia dan Maarif Institute.

Latief, Hilman. 2013. Menelaah Gerakan Modernis-Reformis Islam melalui Kota Gede: Pembacaan Seorang Antropolog Jepang. Studia Islamika. 20(2):377-91.

Latief, Hilman. 2017. Post-Ouritanisme: Pemikiran dan Arah Baru Gerakan Islam Modernis di Indonesia 1995-2015. Yogyakarta: LP3M Universitas Muhammadiyah Yogyakarta.

Mahmood, Saba. 2005. Politics of Piety: The Islamic Revival and The Feminist Subject. New Jersey: Princeton University Press.

Markus, Sudibyo et.al. 2009. Masyarakat Islam yang Sebenar-Benarnya: Sumbangan Pemikiran. Jakarta: Civil Islamic Institute-UHAMKA-UM Malang.

Meijer, Roel, ed. 2009. Global Salafism: Islam's New Religious Movement. New York: Oxford University Press.

Menchick, Jeremi. 2016. Islam and Democray in Indonesia: Tolerance without Liberalism. Cambridge: Cambridge University Press.

Meyer, David S. and Suzanne Staggenborg. 1996. Movements, Counter movements, and the Structure of Political Opportunity. American Journal of Sociology. 101(6):1628-60.

Minardi, Anton. 2018. The New Islamic Revivalism in Indonesia. Journal of Indonesian Islam. 12(2): 247-264.

Mu'thi, Abdul and Ahmad Najib Burhani. 2019. The Limits of Religious Freedom in Indonesia: With Reference to the First Pillar Ketuhanan Yang Maha Esa of Pancasila. Indonesian Journal of Islam and Muslim Societies. 9(1):111-134.

Muhammadiyah, Pimpinan Pusat. 2015. Negara Pancasila sSebagai Dar Al-Ahdi aa Syahadah. Yogyakarta: Pimpinan Pusat Muhammadiyah.

Mujani, Saiful. 2007. Muslim Demokrat: Islam, Budaya Demokrasi, dan Partisipasi Politik di Indonesia Pasca Orde Baru. Jakarta: Gramedia Pustaka Utama.

Mujani, Saiful. 2019. Explaining Religio-Political Tolerance among Muslims: Evidence from Indonesia. Studia Islamika. 26(2):319-51.

Mulkhan, Abdul Munir. 1994. Masalah-masalah Teologi dan Fiqh dalam Tarjih Muhammadiyah. Yogyakarta: Roykhan.

Mulkhan, Abdul Munir. 2000a. Islam Murni dan Masyarakat Petani. Yogyakarta: Yayasan Bentang.

Mulkhan, Abdul Munir. 2005. Kesalehan Multikultural: Ber-Islam Secara Autentik-Kontekstual di Aras Peradaban Global. Jakarta: LSAP.

Nakamura, Mitsuo. 2012. The Crescent Arises over the Banyan Tree: A Study of the Muhammadiyah Movement in a Central Javanese Town, c.1910s-2010. Yogyakarta: Gadjah Mada University Press.

Nashir, Haedar. 2010. Muhammadiyah Gerakan Pembaruan. Yogyakarta: Suara Muhammadiyah.

Nashir, Haedar. 2014. Memahami Ideologi Muhammadiyah. Yogyakarta: Suara Muhammadiyah.

Nashir, Haedar, Zuly Qodir, Achmad Nurmandi, Hasse Jubba, and Mega Hidayati. 2019. Muhammadiyah's Moderation Stance in the 2019 General Election: Critical Views from Within. Al-Jami'ah: Journal of Islamic Studies. 57(1):1-24.

Nathan, K. S. and Mohammad Hashim Kamali. 2005. Islam in Southeast Asia: Political, Social and Strategic Challenges for the 21st Century. Singapore: Institute of Southeast Asian Studies.

Nygren, Katarina Giritli, Lena Martinsson, and Diana Mulinari. 2018. Gender Equality and Beyond: At the Crossroads of Neoliberalism, Anti-Gender Movements, 'European' Values, and Normative Reiterations in the Nordic Model. Social Inclusion. 6(4):1-7.

Peacock, James L. 1978. Purifying the Faith: Muhammadiyah Movement in Indonesian Islam. California: The Benyamin Cummings Publishing Company.

Pranowo, M. Bambang. 2009. Memahami Islam Jawa. Jakarta: Pustaka Alvabet.

https://doi.org/10.24035/ijit.19.2021.203 
Prasetyo, Eko. 2002. Membela Agama Tuhan: Potret Gerakan Islam dalam Pusaran Konflik Global. Yogyakarta: INSIST Press.

Qodir, Zuly. 2009. Gerakan Sosial Islam: Manifesto Kaum Beriman. Yogyakarta: Pustaka Pelajar.

Qodir, Zuly. 2018. Sosiologi Agama: Teori dan Perspektif Keindonesiaan. Yogyakarta: Pustaka Pelajar.

Rahardjo, M. D. 1993. Intelektual, Inteligensia dan Perilaku Politik Bangsa: Risalah Cendekiawan Muslim. Bandung: Penerbit Mizan.

Ricklefs, M. C. 2012. Islamisation and Its Opponents in Java: A Political, Social, Cultural and Religious History, c. 1930 to the Present. Singapore: NUS Singapore.

Saleh, Fauzan. 2001. Modern Trends in Islamic Theological Discourse in 20th Century Indonesia: A Critical Survey. Leiden: Brill.

Salvatore, Armando and Dale F. Eickelman. 2004. Public Islam and the Common Good. Leiden: Brill.

Shihab, Alwi. 2016. Membendung Arus, Respons Muhammadiyah terhadap Penetrasi Kristen di Indonesia. Yogyakarta: Suara Muhammadiyah.

Singh, Bilveer and Zuly Qodir. 2015. Gerakan Islam Non Mainstream dan Kebangkitan Islam Politik Di Indonesia. Yogyakarta: Pustaka Pelajar.

Situmorang, Abdul Wahib. 2013. Gerakan Sosial: Teori dan Praktik. Yogyakarta: Pustaka Pelajar.

Tohari et.al. 2020. Muhammadiyah's Criticism Towards Government Policies in The Era of Din Syamsudin's Leadership. Al-Albab. 9 (1): 19-36.

Wajdi, Firdaus. 2018. The Discourse of Muhammadiyah and Nahdlatul Ulama with Considerations of Geertz Religion of Java. Hayula: Indonesian Journal of Multidisciplinary Islamic Studies. 2(1):49-64.

Weber, M. 2013. The Protestant Ethic and the Spirit of Capitalism. Abingdon: Oxon.

Wickham, Carrie Rosefsky. 2002. Mobilizing Islam: Religion, Activism, and Political Change in Egypt. USA: Columbia University Press.

Wiktorowicz, Quintan. 2004. Islamic Activism: A Social Movement Theory Approach. Bloomington: Indiana University Press.

Williams, Rhys H. 1994. Movement Dynamics and Social Change: Transforming Fundamentalist Ideology and Organization. In M. E. Marty and R. S. Appleby (eds.). Accounting for Fundamentalisms: the Dynamic Character of Movements. Chicago: The University of Chicago Press.

Woodward, Mark R. 1989. Islam in Java: Normative Piety and Mysticism in the Sultanate of Yogyakarta. Arizona: Arizona State University.

Woodward, Mark R. 2011. Java, Indonesia and Islam. Netherlands: Springer.

Zamzami, Mukhammad, Nur Hidayat Wakhid Udin, and Ahmad Fathan Aniq. 2018. Islamism In Madura: From Religious Symbolism to Authoritarianism. Journal of Indonesian Islam. 12(2):159-94. 